\title{
On the school beat: police officers based in English schools.
}

\section{Abstract}

Concerns about youth violence and the radicalisation of pupils have contributed to the deployment of onsite police officers in schools in England. Little is known about the work these officers do. This article firstly outlines the policy background that led to police in schools, then with a focus on the schools in London that have onsite officers, data obtained from a Freedom of Information request are combined with school characteristics data to show that officers are more likely to be based in schools with high levels of pupils from disadvantaged backgrounds. Foucault's work on surveillance is explored in theorising police presence on school sites. The relevance of Agamben's State of Exception is examined in relation to the school-to-prison pipeline in the US. The paper highlights the need for more empirical work in schools to research the impact of onsite police.

Keywords: discipline; police in schools; risk in schools; Safer School Partnerships; surveillance; secondary schools.

\section{Introduction}

Police officers and police community support officers (PCSOs) are often based both full and part-time on primary and secondary school campuses in England. Their presence has been driven by policy initiatives like the Safer School Partnership (SSP) scheme, implemented in 2002. The number of police in schools is not monitored nationally but responses to a Freedom of Information request (FOI) sent to all of the forces in 2014 show that of the 43 police forces in England and Wales (not including the British Transport police and the Ministry of Defence police), 17 of them, all in England, have officers based in schools. ${ }^{1}$

\footnotetext{
${ }^{1}$ Only one of the police forces, Greater Manchester Police (GMP), was unable to answer the questions in the FOI, as the information was apparently not easily retrievable.
} 
Police working in UK schools is an underresearched area. Little is known about officers' work in schools, or how they are perceived by pupils, headteachers, teachers and parents. There are evaluations of the SSP programme (see Bhabra, Hill, and Ghate 2004), research from the police's perspective (Briers 2003), but most of the academic research on the police and schools is focused on other countries, particularly the US. The National Foundation for Educational Research (Lamont, Macleod, \& Wilkin, 2011) produced a scoping study of the various ways police officers are working in schools but pupils and parents' perspectives were not included. However this research did identify the lack of training materials available for school based police officers.

This article outlines the policies underlying the presence of officers in schools, then focuses on schools in London and presents for the first time the number of police working there. It presents Freedom of Information data combined with school characteristics to demonstrate the variation in characteristics of the London schools where officers work. This provides the basis for a theoretical framework to consider the purpose and impact of the policy, in addition to a comparison with the role of police officers in schools in the United States.

\section{Background to police officers working in schools}

The relationship between the police and schools is a longstanding one in many countries, although previously, this relationship was limited to visits by officers conducting crime prevention talks, teaching cycling proficiency and similar activities (Shaw 2004).

Police liaison with schools in England grew out of a more general police liaison with young people, the first specialist juvenile liaison scheme was attempted in Liverpool in 1949 (Gordon 1986). A shift in the juvenile criminal justice system in the 1960s away from punitive measures to a more welfare oriented approach, led to the increasing involvement of 
police in youth-work and schools, and greater contact with social workers and teachers (Gordon 1986). The first School Liaison Officers were appointed in 1966, and by 1975 were employed by several police forces. Gradually, officers were assigned full time to schools, the first in 1980 in Hampshire, participating in the delivery of lessons aimed at preventing youth crime. However the School Liaison Officer role involved visiting schools, rather than being based in a school for much or all of the week.

Since the 1980s, policy makers have been increasingly interested in developing and formalizing the relationships between police and schools, in order to address fears about youth crime and violence (Hopkins, Hewstone and Hantzi 1992; Menter 1987). Liaison between schools and police has been encouraged as a way to improve perceptions of the police and their relations with young people. This policy developed soon after the Conservative government was elected in 1979, and street violence involving the police and young people in Toxteth, Liverpool, and Brixton, London, in 1980 and 1981 (Menter 1987). The HMI report Police Liaison with the Education Service (1983) listed the objectives of the liaison:

a. to make their contribution in helping young people to understand and accept principles of good citizenship and social responsibility;

b. to foster crime prevention in schools, youth clubs and other educational contexts;

c. to develop a broader understanding of the role of the police, and of the parts played by related institutions, such as the courts and the probation service;

d. to offer guidance on the safeguards young people should take to protect themselves and others from danger in the street, at home, in the country, and at play. (DES 1983,2)

High profile incidents during the 1990s elevated fears over school safety, namely the murders at a Dunblane primary school in 1995, and the fatal stabbing of headteacher Philip Lawrence in 1996 (Hayden et al 2011). Following Lawrence's death, a Working Group on school security was established, resulting in the report School Security, Dealing with Trouble 
Makers (Department for Education and Skills (DfES)/ Home Office 1997) which suggested that schools should develop a security strategy. These concerns around safety in schools, along with rising levels of school exclusion and truancy, facilitated increased surveillance in schools and police presence on campuses (Hayden et al 2011; Bhabra et al 2004).

Subsequently the Home Office produced its Street Crime Reduction Strategy (2002), which placed young people and crime front and centre of the policy agenda. In the same year, Police Community Support Officers (PCSOs) were introduced via the Police Reform Act, as a central plank of New Labour's neighbourhood policing policy (Trotman and Thomas 2011). PCSOs have limited police powers, as part of their duties they may be assigned to work either in school or as a School Liaison officer.

Safer School Partnerships (SSPs) were introduced as part of the Blair sponsored Street Crime Initiative. Initially they were formed around 10 so-called 'hotspots' (Hayden et al 2011). These 'hotspots' had been identified by the Street Crime Action Group (SCAG), a cross-departmental group reporting directly to the Prime Minister, $80 \%$ of street crime, including offences such as car-jacking, robbery, possession and use of illegal firearms, occurred in these areas (Bhabra et al 2004). In addition, the DfES was tasked with identifying those Local Education Authorities (LEAs) facing the most difficult challenges with school exclusions and truancy. The 34 LEAs named by the DfES were in nine of the 10 hotspots. The police forces in the 10 'hotspots' and the 34 LEAs were asked to select schools 'they felt would benefit from the presence of a police officer.' (Bhabra et al 2004, 15). Over a hundred schools were nominated and asked if they wanted to join an SSP.

From 2002 to 2005, multi-agency Behaviour and Educational Support teams were instituted around schools with behaviour and truancy problems, as part of the Behaviour Improvement Programme. The police working in SSPs worked with these teams to 'create a safer school 
community' (Hayden et al 2011, 6), no longer solely providing crime prevention education, but assisting in managing pupil behaviour.

SSP guidance had been published in 2002, but different models of SSPs were adopted (and it should be added that police officers can and do work on school campuses outside of the SSP model), leading to revised guidance (Department for Children, Schools and Families (DCSF)/Home Office 2009). The aims of the partnerships are to ensure:

- the safety of pupils, staff and the school site and surrounding area;

- help for young people to deal with situations that may put them at risk of becoming victims of crime, bullying or intimidation, and to provide support to those who do;

- focused enforcement to demonstrate that those who do offend cannot do so without facing consequences;

- early identification, support and where necessary challenge of pupils involved in or at risk of offending;

- improved standards of pupil behaviour and attendance, and less need for exclusions;

- more positive relations between young people and the police and between young people and the wider community; and

- effective approaches to issues beyond the school site that negatively impact on pupil safety and behaviour. (DCFS/Home Office. 2009, 6)

If these aims are compared with the objectives of Police School Liaison from the 1980s, not only are the SSPs' aims almost twice as long, they are also more specific and cover improving pupil attendance and behaviour, early identification and intervention with pupils at risk of offending, and the introduction of 'focused enforcement' for those who break the law. Encouraging citizenship and responsibility has disappeared. The presence of police in schools may be described by a typology, if in the 1980s the role of school liaison officers included the promotion of citizenship, public relations, prevention of crime, and protection of 
pupils, now there is the addition of punishment of pupils, that is the 'focused enforcement', resulting in the five Ps of police work in schools.

An Nvivo text search and word frequency count of the Safer School Partnerships Guidance (2009) revealed that the word 'risk' occurs 36 times, and is $24^{\text {th }}$ of the hundred most frequently used word, more frequent than the words 'youth' (31 instances) and 'parents' (23 instances). The word 'risk' usually occurs in tandem with 'at' and in contexts such as:

help for young people to deal with situations that may put them at risk of becoming victims of crime, bullying or intimidation, and to provide support to those who do (2009, 6) early identification, support and where necessary challenge of pupils involved in or at risk of offending $(2009,6)$

Pupils most at risk of radicalisation are supported through early intervention $(2009,9)$

In contrast, a text search of the HMI report Police Liaison with the Education Service (1983) found only one use of the word risk:

Police officers are involved with young people adjudged to be 'at risk' or on the margins of criminal activity, and attempt to prevent those in trouble for the first time from becoming persistent offenders. (DES 1983, 10)

This occurs in a section on working with individual pupils, and indicates at that time, less emphasis on the possible risks of and to young people.

The SSP guidance has not been rescinded and still serves as the relevant document for SSPs. It should be noted that different types of relationship between police and schools coexist, there are still police forces utilising the Police School Liaison model rather than the SSP, indeed all the police forces in Wales still use the former.

\section{The study- characteristics of schools with police officers}

As mentioned earlier, data were obtained in response to a Freedom of Information request 
(FOI). I sent an FOI to every police force in England and Wales consisting of the following:

(1) As of March $31^{\text {st }} 2014$, how many (if any) police officers and police community support officers in your police force area are working and based in schools (both primary and secondary) either full or part time?

(2) What are the names of these schools?

(3) What is the name and contact details of the person who oversees this area of police work?

Though it is likely that the numbers of officers in schools has subsequently changed, in response to budgetary pressures or local initiatives, these data do give a snapshot of the situation at a particular point in time.

This paper focuses on the response from London's Metropolitan Police. I was interested in this response given comments made by Commander Mak Chishty of the Metropolitan Police at a meeting in November 2013 of the All Party Parliamentary for Children, specifically that his force had been focusing on getting police officers into schools ${ }^{2}$ Most of the officers are based in secondary schools, so this paper focuses on that sector in London. Using School Census data for January 2014 (DfE 2014) I constructed a dataset of all the secondary schools in London, and their percentages of pupils known to be eligible for Free School Meals (used for FSM calculation in performance tables) in order to find out if, as in the US, police officers were more likely to be working in schools with high levels of disadvantage. I used these data as they go up to Year 11, rather than an alternative variable, which is the percentages of pupils known to be eligible for Free School Meals as

\footnotetext{
${ }^{2}$ See minutes of the meeting, available online at http://www.ncb.org.uk/what-we-do/policy/all-party-parliamentary-group/inquiry-2013-2015-childrenand-the-police
} 
this includes pupils who stayed on at schools into Years 12 and 13. The latter data would have produced a skewed dataset as disadvantaged pupils are less likely than their peers to stay on into school sixth forms (DfE 2016). While FSM has limitations as a measure, it is arguably the best indicator of pupil disadvantage currently available (Gorard 2012).

According to the FOI response, 18 of the 33 London Boroughs deploy police officers to work in their schools. In total, 182 secondary schools were reported to have police officers working in them either full or part time; 110 schools in inner London, 72 in outer London. There were some schools that could not be included in the full dataset, as there were no data available for them in the DfE tables. However, these schools have been included in the overall count of schools.

Using the table of all state funded secondary schools in London and their percentage of pupils known to be eligible for Free School Meals (used for FSM calculation in performance tables), schools were grouped according to their percentage. Then, disregarding the four schools for which there were no data, schools with police officers present were grouped separately by increasing percentages and the following table produced:

Table 1

([t]Table 1 near here[/t].

The data clearly show that police officers are more likely to be based in schools with higher levels of pupils eligible for free school meals, that is, with a more disadvantaged population of pupils. Almost all schools where 50 or more percent of pupils are eligible for free school meals have an onsite police officer deployed there. The fact that the percentage of schools with a police officer increases as the percentage of pupils eligible for FSM increases indicates that this is not an accidental occurrence. None of the, albeit small, number of schools that have no pupils eligible for free school meals have an onsite officer. 


\section{Theorising the presence of police in schools}

It has long been argued that the origins of mass compulsory schooling in Britain lay in attempts at social control, particularly of the children of the urban poor (Cunningham 2012; Rose 2000; Walkerdine 1992). Schools are more than enclosures for a certain sector of the population, as Andrew Hope writes:

Schools are institutions of social control that seek to dictate, monitor and enforce 'appropriate' behaviour. Historically, surveillance has played a central role in such processes. $(2015 \mathrm{a}, 2)$

Schools are increasingly adopting diverse methods of electronic surveillance (Hope 2015a). Given the levels of electronic surveillance in place in many schools, Taylor (2012) claims that school pupils in the UK and the US are becoming the most surveilled subgroup of the whole population. In the US some schools have adopted electronic surveillance systems which link directly to local police departments (Lewis 2009), begging the questions why it is deemed necessary to base an officer in a school, and what their physical presence adds to the control and management of pupils. Chadderton (2012) argues that basing police officers on school campuses connects schools to the criminal justice system. Given the dearth of academic research on schools and the police in Britain, it is not known how this connection has affected the nature of schooling. In the US, a far more noxious link between schools and the criminal justice system has been labelled the school- to-prison pipeline', which will be discussed later in this paper.

Foucault's work on surveillance and governmentality offers possibilities for theorising the presence of police officers on schools campuses. Governmentality is the art of government that serves to mould self-regulating citizens, by shaping the subjectivities of individuals and promoting conduct and behaviour conducive to the good of the state (Chadderton and Colley 2012), which resonates with the aims of the SSPs. Surveillance is a 
key mechanism of governmentality, facilitating the monitoring of conduct (Hope 2015b). Chadderton (2012) locates the presence of officers in schools alongside other measures of surveillance.

Famously, in Discipline and Punish Foucault utilised Bentham's proposed prison design, the Panopticon, as a model of disciplinary power, thus the achievement of 'total power through total surveillance' (Bauman 2000, 28). Foucault claimed that 'We live in a society where panopticism reigns' $(1994,38)$, where the mode of power embodied in the Panopticon, has become inherent to our institutions. Those whose work involves the supervision of individuals, 'the school teacher, foremen, physician, psychiatrist, prison warden' (Foucault 1994, 59) exercise the power of panopticism, which is not only about supervision, but also involves constructing knowledge of the supervised. The SSP guidance (2009) is explicit in referring to the gathering of intelligence on young people and their possible criminal, gang or extremist affiliations, but less clear on what happens to that intelligence, how it is stored, who has access to it and the possible ramifications for the young people concerned.

The Panopticon is about complete visibility, it gives the watched the impression that they may be under surveillance at any time as they are always visible from the central tower, but the watchers may be hidden from sight (Gane 2012). The inescapable feeling of being watched has a normalizing function on the incarcerated, who adapt their behaviour accordingly. The police officer acting alone cannot replicate this function as s/he does not have the same vantage point. One possibility is that police officers act in concert with school staff to form a network of surveillance.

The police officer differs from the Panopticon in other ways, the officer can watch, but s/he may also intervene. Andrew Briers, the first police officer to be deployed in a British school, has compared his role to that of 'school resource officers' (SROs) in the US, as 
officers deployed in schools there are known. According to Briers, the work of an individual SRO in a school follows a triad model, composed of three different roles: "the Teacher (Law related)"; "Counsellor (Law Related)"; and "Law Enforcement Officer" (Briers 2003, 130). An officer will occupy each role at different times and for different periods of time.

It is the second of these two roles that is relevant here. In order to gather intelligence and function effectively, an individual officer must make his/her self available to school pupils and form relationships with them. Briers (2003) recounts the various social and extracurricular activities he undertook with pupils, such as a swimming club and the formation of a police cadet unit for lower secondary age pupils. Whilst ostensibly benign, these activities allow police officers to have unfettered, informal access to pupils. Police officers surveil and gather intelligence, but in addition their bodies represent the power of the state and the criminal justice system, making the business of crime control routine (Monahan and Torres 2009).

According to Gane (2012), the publication of Foucault's lectures on biopower at the Collège de France during 1978-9 provide an additional dimension to Foucault's work on the art of government, through an analysis of the relations between the state and the market, thus pantopticism may be seem as a form of 'liberal governance' $(2012,612)$ that concerns the ability of the state to surveil and control the market. The current era of neoliberal government is characterised by the rollback of state welfare provision, but also by an increase of state surveillance and control, particularly of more troublesome social groups (Chadderton and Colley 2012; Olsen et al 2004). Gane (2012) further argues that under neoliberal government, the conduct of the state is increasingly dictated by the market. Police officers working in schools could contribute to the marketisation of schools; their presence may appeal to some parents who assume that this guarantees a safer environment for their child. 
The relations between the neoliberal state and the market raise questions about the role of surveillance, and Gane describes surveillance as: 'discipline, control, interactivity and as a mechanism for promoting competition' $(2012,614)$

Accordingly, surveillance may function to promote competition amongst individuals, for example, schools under the surveillance of the state via performance tables, pressure pupils to compete for the highest grades in order to make themselves more marketable in later life. In any competition there are always those who lose and neoliberalism needs an answer for what to do with them. The most economically advantageous solution would be to identify early on those that cannot be productive and enterprising citizens (Olsen et al 2004), and weed them out. As Chadderton $(2014,422)$ writes:

\footnotetext{
Rather than providing employment or welfare support for young people from disadvantaged backgrounds, neoliberal governments invest in policing and surveillance of these groups perceived as 'disposable'.
}

This fits with Rose's (2000) description of life in risk societies. As mentioned earlier, the frequency of the word 'risk' in the SSP guidance (2009) demonstrates a concern with the riskiness of children and young people, the risk they pose to each other, the community, and also their perceived vulnerability to harm, thus according with Kelly's (2003) argument that anxiety over the perceived potential hazards both to and caused by young people has contributed to the increase of surveillance. Rose argues that current modes for governing conduct do not aim to erase people's capacity for agency, rather they:

Seek to foster and shape such capacities so that they are enacted in ways that are broadly consistent with particular objectives such as order, civility, health and enterprise. (2000, 185).

But there are, inevitably, those who will refuse, or be unable to adapt to, such shaping. Rose (2000) argues that modern crime control strategies may be divided into two groups, 
those that shape conduct by enfolding subjects into 'circuits of inclusion' and those that manage the deviant through 'circuits of exclusion' $(2000,187)$. What he refers to as 'control workers' (a group that includes teachers, police and social workers) use the management of risk to control society, by identifying levels of risks posed by subjects and their actions, and they:

Seek to link up in circuits of surveillance and communication in a perpetually failing endeavour to minimise the riskiness of the most risky $(2000,199)$

Clearly, those schools which become host to a resident police officer have been identified as populations at risk and been accorded the appropriate intervention. Page (2016) reports that the impact of technological advances on surveillance practices has caused theoretical perspectives on surveillance in education to shift towards developing models of post-panopticism. However, these models are largely derived from Deleuze's work on control societies, and relate to the use of technology to exercise power, which is applicable to electronic surveillance but does not fit the work undertaken by police in schools.

It has been argued that there has been a return to sovereign power as the dominant form of governance in the west, particularly since September $11^{\text {th }} 2001$, and the bombings in London in 2005 (Butler 2004). Giorgio Agamben's (2005) work State of Exception has been utilised in understanding the positioning of those living on the margins of society, including in schools in the US. This will be addressed in the next section in considering the role of police officers in schools in America.

\section{The United States of Exception?}

Although the federal nature of the US and the adoption of different programmes in different states make it difficult to ascertain when police started working in schools, the first police officers deployed to work on school campuses in the US are thought to have been in Flint, 
Michigan during the 1950s (Kupchik and Bracy 2009: Brown 2006), considerably earlier than their UK counterparts. However, it was not until the 1990s, after a notorious spate of school shootings that SROs began to be deployed in significant numbers, facilitated by legislation such as the Safe Schools Act (1994), a law that awarding funding to schools which adopted violence prevention measures.

Since then, numbers have grown substantially. As with the UK, it is difficult to know precise figures, but Kupchik and Bracy (2010) highlight that in 2008, the professional body for SROs, the National Association of School Resource Officers, claimed to have nine thousand members and that this may underestimate the actual figure given that not all SROs are members. SROs are predominantly deployed in schools in poor, urban neighbourhoods (Price 2009: Casella 2002). Kupchik and Bracy (2010) claim there is little knowledge on how these officers conduct themselves, and a dearth of analysis and theorising on the appropriateness of deploying officers in schools. The SROs are part of a suite of violence prevention measures, others include the installation of metal detectors at school entrances, CCTV, and zero tolerance policies. In 2012, The Guardian newspaper ran an article on the use of tasers by police working in schools in Texas, for disruptive behaviour that would previously have been dealt with by teachers (McGreal 2012).

I have already briefly mentioned the existence of the school-to-prison pipeline in the US. This metaphor describes the greatly increased contact between school pupils and the criminal justice system as a consequence of the violence reduction measures implemented by US schools. Price (2009) claims that the presence of police working in schools is a fundamental aspect of the school-to-prison pipeline. The combination of zero tolerance policies towards incidents of violence, and the presence of a police officer able to treat incidents as criminal has resulted in extreme overreaction to pupil misbehaviour. Price (2009) describes the police being called to deal with a five year old girl who had a temper tantrum in 
kindergarten. This child was handcuffed and sequestered in a police vehicle for three hours. The school-to-prison pipeline impacts on poor and minority populations in a disproportionate way and has contributed to a striking rise in the number of young people who become entangled with the criminal justice system (Price 2009). In these cases, the police officers working in schools are functioning in the manner described in the previous section, identifying and excluding those who are deemed likely to become risky citizens.

In-depth qualitative research has been conducted in the US, focusing on the impact of officers in schools, and their relationships with pupils. Studies have included ethnographic approaches, observations conducted in schools, focus groups with pupils, and interviews with students, principals and other administrative staff, teachers and police officers (Kupchik and Bracy 2010; Weiss 2010; Nolan 2009; Weiss 2009). The schools in these studies experienced law enforcement in the form of local police officers, officers from a task force on safety in schools, and security staff, working under the control of the city police department, a more intensive approach than that in schools in England. Nolan (2009) and Kupchik and Bracy (2010) found that officers intervened when students broke school rules, rather than committing criminal offences. More often than not, these confrontations with officers escalated, with students subjected to various crime control strategies. Approaches by officers to students who had not yet committed an infringement of the school rules also frequently occurred, these too

would often evolve, through a series of exchanges and actions, into an "official police matter", and students would end up in handcuffs with a summons to criminal court. (Nolan 2009, 33).

Nolan (2009) points to a pattern across similar schools, of an increase in the use of courts summons. Many such summons were for the offence of 'disorderly conduct', an ambiguous and subjectively used term open to wide interpretation, not unlike the offence of 
anti-social behaviour in the UK. Nolan refers to a segment of the high school population who are 'learning to do time' (Nolan and Anyon 2004 in Nolan 2009, 44). Many of these students do not finish high school and are unlikely to find paid work in their communities, particularly without a high school diploma.

Weiss found that it was common for students to claim they experienced anxiety at what Weiss (2010, Chapter 12) called 'the constant gaze of suspicion', due to their experiences of being surveilled both in and out of school. Yet Weiss (2010) also claims that the young people in her study exercised various forms of resistance, ways of managing and responding to the presence of police, security agents and electronic surveillance. These forms of resistance ranged from outright protest, for example the mass walkout of approximately 1500 students in protest at the installation of metal detectors at their school, to more subtle actions such as what Weiss calls 'tactical avoidance' (2010, Chapter 12), i.e. taking different routes around school to avoid interactions with security agents.

Some young people in Weiss's study attempted to develop friendly relations with members of security staff, by exchanging greetings and small talk with the staff, Weiss refers to this as 'resistance as appropriation' (2010, Chapter 12). There was a gender element to this, in that some girls referred to flirting with the security agents to gain advantages, for example entry to an area of the school, but for others, the attentions of the security staff were unsought and unwelcome 'Like I hate passing by a crowd of guys in the first place, but then when I have to go to school with people who are supposed to protect me, but they're hitting on me you know.'(Weiss 2010, Chapter 12).

In contrast, Kupchik and Bracy (2010) found more positive perceptions in their study, which involved four public high schools in two different US states, rather than the one school studied in Weiss's research. Their sample of four schools included two from each state, one 
with mainly white middle-class students and one with a large number of students from minority ethnic and disadvantaged backgrounds.

Kupchik and Bracy (2010) found that the roles of the SROs differed according to the needs of the school. Most of the SROs did attempt to act as student mentors, although others did not see this as part of their role, or were discouraged from doing so by the school administration. Kupchik and Bracy admit that their initial expectation was that students would resent the SROs' presence on campus, yet nearly all their student interviewees were positive about this, because they thought SROs deterred crime on campus and were able to intervene in crises. In the main, the presence of the officers made the students feel safer. However, they were less positive about SROs acting as mentors, and the observational data highlighted ways in which being a mentor conflicted with being a police officer, for example if students disclosed involvement in illegal activity, which officers are duty bound to deal with.

Lewis (2006) has applied Agamben's work on the state of exception and his theory of the camp to theorise anti-violence strategies in US schools, including the presence of police officers. Agamben (2005) writes that the state of exception is difficult to define, but that it exists at the limits of the law:

The state of exception is not a dictatorship (whether constitutional or unconstitutional, commissarial or sovereign) but a space devoid of law, a zone of anomie in which all legal determinations- and above all the very distinction between public and private- are deactivated. (Agamben 2005, 50)

It is a state where the law can be set aside, notably law relating to human rights. A contemporary example would be the treatment of prisoners in the detention centre at Guantanamo Bay, who may be held indefinitely without trial or charge. Agamben argues that the physical space of the camp, is the 'spatial inscription' (Lewis 2006, 162) of the state of 
exception, a space where ordinary life is left outside, and the norms of the everyday do not apply. Individuals inhabiting the camps are reduced to a state of bare life. Drawing on Walter Benjamin's work, Agamben claims that oppressed people live permanently in a state of exception, and thus that the state of exception has become an actual 'technique of government' $(2005,6)$.

Lewis gives several examples of situations in the US where, as a consequence of zero tolerance policies and increasing involvement with the police, schools, particularly urban high schools, have become states of exception, for example:

November 5, 2003, at Goose Creek High School in South Carolina. That morning, the school was raided and militarily secured by a fully armed SWAT team. Soldiers wielding loaded weapons physically thrust students to the ground and slammed them against lockers; anyone who did not immediately respond to orders was handcuffed. The commando team proceeded to search the premises but in the end found neither drugs nor weapons of any kind. In the name of security, education as the normative practice of schooling was suspended, initiating a lockdown scenario in which students were subjected directly to force that in its implementation exceeded due cause. (Lewis 2006, 168)

Such scenarios are as yet unknown in England and at this time, it would be extreme to apply Agamben's work on the state of exception and the camp to the work of police officers in schools of England. However, Chadderton and Colley (2012) claim, in relation to policies on transitioning young people from school into work, and the growing marginalisation of some young people that:

we would argue that they nevertheless contain elements of the state of exception, and contribute to its creeping encroachment into ever more areas of civil society. $(2012,340)$

It is possible that this is also applicable to the work of police in schools in England and it is worrying to contemplate where this 'creeping encroachment' could lead. 


\section{Conclusion}

This paper addresses an underresearched area and demonstrates for the first time the extent to which police officers are based in London schools. There are limitations to the study, further analysis could be done using data for levels of exclusions from schools, proportions of ethnic groups, and GCSE pass rates, to add to the description of types of schools in which police officers are more likely to work.

As with schools in the US, police officers or PCSOs are more likely to be deployed in inner city schools with disadvantaged populations (Price 2009: Casella 2002). That is not to claim that the levels of disadvantage are the cause of a police officer's deployment. There are other factors which could have contributed, for example schools may be in areas of high street crime, as with the original 'hot spots' in the first Safer School Partnerships. This finding, along with the current absence of academic research and theorising on the role of police in schools, suggests that the work of these police officers requires further exploration. It is possible that police officers adopt different roles in relation to pupils at different times to accomplish particular ends. The literature from the US highlights that although students may feel their schools are safer with an SRO, for some pupils the latter's inappropriate interventions in school discipline have proved disastrous and precipitated their entry into the youth justice system. This paper argues that there is a need for in-depth work in schools in England to research the perspectives of pupils, teachers and police officers, and to discover the impact that officers are having on children and young people. It is also necessary to develop an appropriate theoretical framework for understanding the presence of officers in schools. It could be that officers are acting in a surveillance role, or involved in a process of 'social sorting' (Jenkins 2012, 160), whereby those pupils who are deemed unlikely to become productive citizens are identified early and either experience an intervention from a kindly officer and become reformed, or they are weeded out and pushed further to the 
margins. Given the Prevent Strategy (2011), and recent concerns about young people absconding to fight in wars abroad, links between the police and schools are likely to strengthen and more officers may work in schools.

The following is from the HMI Report on school liaison, discussed earlier:

Because of the need to encourage and develop in pupils the initiative, enterprise and intellectual vigour needed to respond to new and changing realities, schools cannot be in the business of promoting an unquestioning acceptance of authority however exercised. (DfE 1983, 13)

It is difficult to imagine such sentiments being expressed today. Arguably the very least the presence of a police officer in a school does is naturalize their presence to the gaze of pupils, making their authority, in large part, unquestioningly accepted and reinforcing the authority of the state. Police enforce the law in a democratic society with the consent of the governed, but it is not known to what extent pupils have consented to, or have even been consulted about the presence of police in schools, or to what extent officers are expected to intervene in school discipline. It is also unknown how many pupils enter the criminal justice system directly as a consequence of contact with a police officer working on their school campus. As yet, perhaps because we do not have the toxic combination of zero tolerance towards violence policies as well as campus police officers, the UK does not have the equivalent of the school-to-prison pipeline. However, the development of such a pipeline should be seen as within the realm of the possible.

It remains to be seen if police on campuses in England are a benevolent force, protecting pupils and preventing crime, or if they are part of a network of surveillance, acting to filter out 'risky' individuals who are unlikely to become productive citizens, and push them even further to the margins where the 'disposable' subjects of neoliberal society increasingly dwell. 
Acknowledgements: With thanks to Professor Carl Parsons of the University of Greenwich for feedback on an earlier draft, and also to Richard Quibell of the University of Greenwich for advice on data.

\section{References}

Agamben, G. 2005. State of Exception. Chicago and London: Chicago University Press.

Bauman, Z. 2000. "Social Uses of Law and Order." In Criminology and Social Theory edited by D. Garland, and R. Sparks, 23-45. Oxford: Oxford University Press.

Bhabra, S., E. Hill, and D. Ghate, 2004. Safer School Partnerships: National Evaluation of the Safer School Partnerships Programme. London: Youth Justice Board and Department for Education and Skills.

Briers, A. N. 2003. "School-based police officers: What can the UK learn from the USA?" International Journal of Police Science \& Management, 5(2): 129-142.

Brown, B. 2006. "Understanding and assessing school police officers: A conceptual and methodological comment." Journal of Criminal Justice, 34(6): 591-604.

Butler, J. 2004. Precarious life: The powers of mourning and violence. London, New York: Verso.

Casella, R 2002: "Where policy meets the pavement: Stages of public involvement in the prevention of school violence." International Journal of Qualitative Studies in Education, 15 (3): 349-372

Chadderton, C. 2012. "UK Secondary Schools under surveillance: what are the implications for race? A Critical Race and Butlerian analysis." Journal of Critical Education Policy Studies, 10 (1): 76-92

Chadderton, C. 2014. "The militarisation of English schools: Troops to Teaching and the implications for Initial Teacher Education and race equality.” Race Ethnicity and Education, 17(3): 407-428.

Chadderton, C. and H. Colley. 2012. "School-to-work transition services: marginalising 'disposable'youth in a state of exception?" Discourse: studies in the cultural politics of education, 33(3): 329-343

Cunningham, H. 2012. The invention of childhood. London: Random House.

Department of Education and Science. 1983. Police Liaison with the Education Service: A report of an enquiry carried out by Her Majesty's Inspectors of Schools in July 1982. London: HMSO 
Department for Education.2014. School Pupils and their Characteristics January 2014 Underlying data SFR15/20/4 available at:

https://www.gov.uk/government/statistics/schools-pupils-and-their-characteristics-january$\underline{2014}$

(accessed 20 November 2016)

Department for Education. 2016. Destinations of key stage 4 and key stage 5 students in state-funded and independent institutions, England, 2013/14 SFR 05/2016, 21 January 2016

DfES/Home Office. 1997. School Security, Dealing with Trouble Makers. London: DfES.

Foucault, M. 1994. Power: Essential works of Foucault 1954-1984 Volume 3. London: Penguin.

Gane, N. 2012. "The governmentalities of neoliberalism: panopticism, post-panopticism and beyond." The Sociological Review, 60(4): 611-634.

Gorard, S. 2012. "Who is eligible for free school meals? Characterising free school meals as a measure of disadvantage in England." British Educational Research Journal, 38(6): 1003-1017.

Gordon, P. 1984. “Community policing: towards the local police state?" Critical Social Policy, 4(10): 39-58.

Hayden, C., A. Holt, D. Martin and C. Nee. 2011. "Safer schools in the UK-A case study." The International Journal on School Disaffection, 8(2): 5-13.

Home Office. 2002. Street Crime Reduction Strategy. London: Home Office

DCFS/Home Office. 2009. Safer School Partnerships Guidance. London: Home Office/DCFS

Hope, A. 2015a "Biopower and school surveillance technologies 2.0", British Journal of Sociology of Education, DOI: 10.1080/01425692.2014.1001060

Hope, A. 2015b. "Governmentality and the 'selling' of school surveillance devices." The Sociological Review, 63(4): 840-857.

Hopkins, N., M. Hewstone and A. Hantzi. 1992. "Police-Schools Liaison and young people's image of the police: An intervention evaluation.” British Journal of Psychology, 83(2): 203-220.

Kelly, P. 2003 “Growing Up as Risky Business? Risks, Surveillance and the Institutionalized Mistrust of Youth," Journal of Youth Studies, 6 (2): 165-180 
Kupchik, A. and N. Bracy. 2010. "To Protect, Serve, and Mentor? Police Officers in Public Schools.'In Schools under surveillance: Cultures of control in public education edited by edited by T.Monahan and R.D. Torres. Rutgers University Press. Chapter 1Kindle edition

Jenkins, R. 2012. “Identity, surveillance and modernity: Sorting out who's who.” In Routledge handbook of surveillance studies, edited by K. Ball, K. D. Haggerty and D. Lyon. 2012.London: Routledge.

Lamont, E., S. Macleod and A. Wilkin. 2011. Police Officers in Schools: A scoping study. NFER Report. Slough: NFER

Lewis, T. E. 2006. "The school as an exceptional space: Rethinking education from the perspective of the biopedagogical." Educational Theory, 56(2): 159-176.

Lewis, T. 2010. "Risky Youth and the Psychology of Surveillance: The Crisis of the School Shooter". In Schools under surveillance: Cultures of control in public education edited by T. Monahan and R.D. Torres. Rutgers University Press. Kindle edition

McGreal, C. 2012 “The US schools with their own police.” The Guardian 9 January 2012 available on line at:

https://www.theguardian.com/world/2012/jan/09/texas-police-schools

Menter, I. 1987. "The long arm of education: a review of recent documents on police/school liaison." Critical Social Policy, 7(21): 68-77.

Monahan, T. and R.D. Torres. 2010. "Introduction." In Schools under surveillance: Cultures of control in public education edited by T. Monahan and R.D. Torres. Rutgers University Press. Kindle edition

Olssen, M., J.A. Codd and A.M. O'Neill. 2004. Education policy: Globalization, citizenship and democracy. London: Sage.

Page, D. 2016. "Conceptualising the surveillance of teachers." British Journal of Sociology of Education: 1-14. DOI: 10.1080/01425692.2016.1218752

Price, P. 2009. "When is a police officer an officer of the law? The status of police officers in schools." The Journal of Criminal Law and Criminology, 541-570.

Shaw, M. 2004. Police, Schools and Crime Prevention: A preliminary review of current practices. International Centre for the Prevention of Crime.

Rose, N. 2000. "Government and Control.” In In Criminology and Social Theory edited by D. Garland, and R. Sparks, 183-208. Oxford: Oxford University Press. 
Taylor, E. 2012. "The rise of the surveillance school" Routledge handbook of surveillance studies edited by K. Ball, K. D. Haggerty and D. Lyon. 225-231. London and New York: Routledge.

Trotman, D. and L. Thomas. 2016. "Police Community Support Officers in Schools: Findings from an Evaluation of a Pilot Training Programme for School Liaison Officers." Policing, paw006.

Walkerdine, V. 1992. "Progressive Pedagogy and Political Struggle.” In Feminisms and critical pedagogy. Edited by C. Luke, and J. Gore, 15-24 London: Routledge.

Word count: 7443 